\title{
Implementation of Occupational Safety and Health in Health Facilities in The Prevention of COVID-19 in Bogor Regency
}

\author{
${ }^{1}$ Novita Ridha Amelia, ${ }^{2}$ Dewi Purnamawati \\ Faculty of Public Health, Muhammadiyah University of Jakarta \\ K.H. Ahmad Dahlan St, Cireundeu, Ciputat, South Jakarta, 15419 \\ E-mail: amelia.yuuk@gmail.com
}

\begin{abstract}
Covid-19 has spread to several countries including Indonesia. Responding to the growing trend of the spread and transmission of Covid-19 which continues to increase, it is necessary to identify, overcome, and prevent it through the implementation of Occupational safety and health (K3). This study uses a descriptive research method with a case study approach. Implementation in health facilities is still not optimal, as seen from the increasing number of affected health workers. In this study, the authors wanted to see indicators of officer compliance in implementing K3, supporting facilities and infrastructure, monitoring and evaluation from the Bogor District Health Office. The importance of implementing K3 in health facilities for health workers as the front line of health services dealing with Covid-19. This is indicated by the number of health workers affected by Covid-19. Implementation of K3 in health facilities to reduce the number of health workers
\end{abstract}

Keywords: Covid-19, Occupational safety and health, Health facilities 


\section{INTRODUCTION}

Coronavirus diseases-19 (COVID-19) has been declared a world pandemic by WHO (WHO, 2020). Coronavirus is a zoonotic or virus that is transmitted between animals and humans. This virus and disease are known to have originated in the city of Wuhan, China since December 2019. As of March 21, 2020, the number of cases. This disease has reached 275,469 people spread across 166 countries, including Indonesia. Starting from December 31, 2019, to mid-June 2020, even until the end of 2020, Indonesian people experience prolonged suffering caused by the emergence of a new type of infectious disease called Corona Virus 2019 (IFSW, 2020). The virus that causes Covid-19 is called SARS-CoV-2 (Kemenkes,2020).

Global data as of 16 May 2021 are: 162,177.376 confirmed, with 3,364,178 deaths (CFR $2.1 \%$ ). Indonesian data, the number of people examined was $10,409,178$ people, negative $8,669,428$ people, confirmed Covid-19 as many as 1,739,750 people, recovered 1,600,857 people and died 48,093 (CFR 2.8\%). For ASEAN countries, Indonesia's confirmed cases are still the highest, while for provinces in Indonesia the highest cases are still in DKI Jakarta, West Java, and Central Java.

Presidential Decree (KEPPRES) No. 12 of 2020 concerning the Determination of NonNatural Disasters for the Spread of Corona Virus Disease 2019 (Covid-19) as National Disasters, and others.

In the Regulation of the Minister of Health of the Republic of Indonesia No. 52 of 2018 concerning occupational safety and health in health service facilities.

Article 1 paragraph 1 states that Health Service Facilities, hereinafter referred to as Fasyankes, are tools and/or places used to organize health service efforts, whether promotive, preventive, curative, or rehabilitative carried out by the central government, regional governments, and/or the community.

Article 1 paragraph 2 states that Occupational Health and Safety in Health Service Facilities, hereinafter referred to as $\mathrm{K} 3$ in Health Service Facilities, are all activities to ensure and protect the human resources of health service facilities, patients, patient companions, visitors, and the community around the Health Service Facility environment so that they are healthy, safe, and free from health problems and adverse effects resulting from work, environment, and work activities.

The ILO Declaration of the Century which was adopted in June 2019 declares "safe and healthy working conditions as the basis of decent work". This is even more important today, given the importance of ensuring workplace safety and health in pandemic management and the ability to return to work.

In workplaces in various fields of work each agency has a risk of health and safety hazards to the workforce, in reducing the risk of harm, each agency can implement K3 management which is one of the requirements of the activities section in an agency to achieve productivity and efficiency in the 
workplace. workplace. As Law No.36/2009 concerning Health, that workplaces are required to carry out occupational health efforts if the workplace has a risk of health hazards and or has at least 10 workers (Wati et al, 2018).

Several factors that cause potential hazards that can lead to illness and accidents due to work in hospitals are biological factors such as bacteria, viruses, fungi; physical factors such as lighting, noise, temperature, radiation, and others; chemical factors such as anesthetic gases and antiseptics; ergonomic factors and social factors such as relationships between fellow workers and with superiors, motivation and work stress. In addition, work accidents can also occur due to factors from the workers themselves such as inadequate quality and skills of workers, lack of awareness of workers so that they underestimate the risk of work by not using the personal protective equipment that has been provided, then high levels of work stress and lack of work. motivation at work (Salmawati et al, 2015).

The following elements of universal precautions protect against this action: Wash hands, Wear appropriate protective equipment, Management of sharps (provided a special place for disposing of syringes and syringes), Decontamination, sterilization, disinfection, Waste management.

Health workers who work as the front line in carrying out the COVID-19 emergency response are at higher risk than various groups of workers. According to reports from Italy and China, from the number of confirmed positive, there are about $20 \%$ of health workers (The Lancet, 2020).

For health facilities in Bogor Regency from March 2020 to May 2021, many health workers have been affected by the Covid-19 pandemic.

Table 1. Number of Health Workers Confirmed by Covid-19

\begin{tabular}{cccc}
\hline Hospital & Public Health Center & Healthy Facilities \\
\hline 1207 & 544 & 1873 & 122 \\
Total & & 1873 & \\
\hline
\end{tabular}

Data source: Bogor District Health Office until May 2021

Table 2. Number of Health Workers who Died Confirmed by Covid-19

\begin{tabular}{ccc}
\hline Hospital & Public Health Center & Healthy Facilities \\
\hline 3 & 6 & 0 \\
Total & & 9 \\
\hline
\end{tabular}

Data source: Bogor District Health Office until May 2021

Table 3. Number of Health Workers Suspect Covid-19 in 2021

\begin{tabular}{cccc}
\hline & Hospital & Public Health Center & Healthy Facilities \\
\hline January & 280 & 128 & 1 \\
\hline February & 313 & 1.522 & 9 \\
\hline March & 37 & 45 & 3 \\
\hline April & 45 & 597 & 0 \\
\hline
\end{tabular}

Data source: Bogor District Health Office until April 2021 
Restrictions on physical contact, social distancing, and regular hand hygiene practices are still being carried out and are believed to be one of the ways to prevent the transmission of the virus. Like viral diseases in general, until now there has not been found a definitive treatment for Covid 19.

The limited capacity of hospitals and limited health personnel are still obstacles in Indonesia. Restrictions on social activities that do not work will have an impact on the explosion of the number of cases in the community and on medical personnel. Many hospitals today are still facing a shortage of PPE needed in handling patients. OHS risk management is an effort to recognize and at the same time control various risks that threaten the safety of the workforce. In a pandemic situation, it is necessary to adjust various aspects to reduce the risk of virus transmission in hospitals and health facilities.

The problem is whether the implementation of $\mathrm{K} 3$ can reduce the number of health workers affected by Covid-19 at health facilities in Bogor Regency.

How the implementation of $\mathrm{K} 3$ can reduce the number of health workers affected by Covid-19 in health facilities in Bogor Regency.

\section{METHODS}

This study uses a descriptive research method with a study approach cases to find out the relationship between the implementation of K3 and health workers affected by Covid-19. The sample used was health workers affected by Covid-19 at health facilities in Bogor Regency. Collecting data from the Bogor District Health Office.

\section{RESULTS AND DISCUSSIONS}

Protection for health workers who are at the forefront of handling Covid-19 is considered not optimal. As a result, medical personnel is vulnerable to the disease. This Covid-19 pandemic also renews the rights and responsibilities for health and safety in the workplace for health workers according to International Labor Organization (ILO) standards.

In the previous table, it can be seen in Table 1. Showing the number of confirmed Covid-19 health workers, the number in hospitals is higher than in other health facilities.

Table 2. Shows the number of confirmed Covid-19 health workers who died, it can be seen that the number at the Public Health Center is higher than other health facilities.

Table 3. This shows that the number of health workers with suspected Covid-19 is seen to be more in the Public Health Center than at other health facilities.

From the three tables above, it can be seen that health workers are affected by Covid-19. This must be a special concern to continue to improve the implementation of $\mathrm{K} 3$ in health facilities.

From the table data above, it can be concluded that from the three types of health facilities, 
health workers affected by Covid-19 were quite high and some even died. In response to the surge in cases of Covid-19 patients. Health facilities always cooperate with the Covid-19 task force at the district level, hospitals, health offices, Public Health Center, and other health facilities such as clinics, etc. to implement K3 implementation and fulfill PPE needs. This is done so that health facilities can anticipate risk factors for work and the work environment so that they can serve the maximum number of Covid-19 patients in Bogor Regency properly, accurately, and correctly without feeling anxious.

Based on data obtained from the Bogor Regency Health Office, from March 2020 to May 2021, health workers affected by COVID-19 have increased both in hospitals, health centers, or other health facilities. This is because health workers are at the forefront of handling Covid-19.

The highest confirmed cases are in hospitals because hospital staff is directly serving patients with Covid-19. Meanwhile, more health workers confirmed positive for COVID-19 who died at the Public Health Center. This still needs further research whether it is due to late handling or other things.

For suspected Covid-19, initially many health workers were in hospitals, but after the implementation of the vaccine in health workers, the number of suspected cases of Covid-19 was more in this Public Health Center, further research was needed, whether it was because of a sense of security and ignoring health protocols because they had been vaccinated against Covid-19 19 is due to other factors.

In the context of COVID-19, various types of measures can be implemented to reduce the risk of transmission among health care workers and emergency workers, such as Environmental and engineering controls aimed at reducing the spread of pathogens and contamination of surfaces and objects. This will include providing adequate space to allow physical distancing between patients and patients and between patients and health care workers and ensuring the availability of well-ventilated isolation rooms for patients with suspected or confirmed COVID-19 (WHO, 2020).

Administrative measures aim to prevent risky behavior. This includes adequate referral sources for infection prevention and control (PPI) measures, such as proper infrastructure, development of a clear IPC policy, facilitated access to laboratory testing, proper triage, and patient placement, adequate staff-to-patient ratio, and staff training. (WHO, 2020).

Another administrative action that must be implemented relates to health monitoring and supervision of workers at risk to detect the unfavorable health effects of occupational hazards at an early stage considering that at this early stage it will be easier to treat illness (eg by monitoring workers with fever or workers with symptoms other beginnings of infectious disease). Arrangements should be made to ensure that any exposed person can easily report any symptoms to his or her supervisor who will then inform the medical staff (WHO and ILO, 2018).

Proper PPE is also important. This involves selecting the right PPE and training on how to put 
it on, take it off and dispose of it (WHO, 2020).

WHO has developed guidelines on the rights, roles, and responsibilities of health workers during the COVID-19 outbreak (WHO, 2020).

Laboratory personnel. The use of bacteria, viruses, blood, tissue, and/or body fluids in the laboratory can cause infection. Diseases carried by humans and animals used in research can also be transmitted by teams, who can then become carriers (WHO \& ILO, 2018). The WHO Biological Safety Manual provides practical guidance on techniques and measures that can be used in laboratories at all levels to prevent transmission.

In addition, specific guidelines on Covid-19 have been developed including recommendations addressing basic working conditions related to specific manipulations in laboratory settings (WHO, 2020)

Funeral worker. Human remains can pose a health risk in some cases of infectious diseases. Workers involved in the management of corpses including morgue services, funerals, autopsies, or burials may be at risk of contracting infection, including in the case of Covid-19, and should take appropriate precautions by practicing good hand hygiene, PPE, good ventilation of the work area and equipment cleaning (WHO, 2020).

Emergency transport worker. During an outbreak, there may be a need to transport patients (by ambulance as well as by special flights, trains, and ships) which puts these workers at risk of infection. Those who transport the bodies of people who have died from infectious diseases are also at risk. Cleaning and sterilizing vehicles also pose a risk of infection (WHO and ILO, 2018).

Cleaning and waste management personnel in health and emergency care facilities. The risk of Covid-19 infection for these workers may arise from contact with potentially contaminated materials, surfaces, and environments (WHO \& UNICEF, 2020). For workers tasked with managing the waste of this facility, proper hand hygiene, PPE, and disinfection methods must be used.

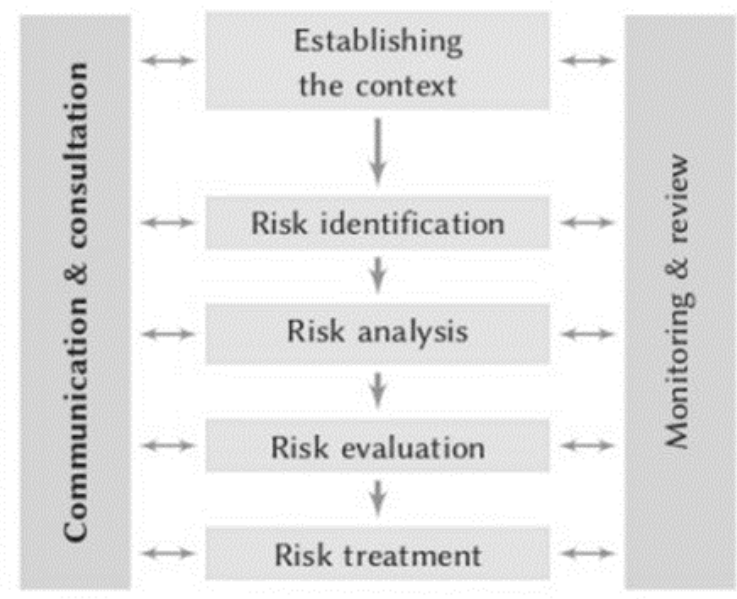

Figure 1. Risk Management Process In ISO 31000: 2018 


$$
\begin{gathered}
\text { E-ISSN: } 2808-5361 \\
\text { http://e-journal.fkmumj.ac.id/ }
\end{gathered}
$$

\section{Proceeding The First Muhammadiyah Internasional- Public Health and Medicine Conference}

In the risk management process we need to do the following:

1. Occupational Risk Assessment.

2. Work Environment Risk Assessment

3. Risk Communication

The above steps are then followed by monitoring and evaluation steps. Monitoring is used for further actions that must be taken in this pandemic response situation. Evaluation is carried out on the potential hazard aspects of the control method and the impacts that arise. Evaluation can be done by brainstorming, fishbone, or other easier ways. The results of the evaluation are submitted to the management team for feedback or input.

\section{CONCLUSION AND SUGGESTIONS}

The Covid-19 pandemic leaves deep sorrow for health workers and families who have died due to Covid-19. The struggle is not over yet, health workers as the front line must be passionate about providing medical services to Covid-19 patients.

Policies regarding the importance of implementing K3 in health facilities must be carried out consistently and responsibly. With strict monitoring and evaluation.

The compliance of health workers in implementing $\mathrm{K} 3$ also has an effect during this pandemic.

The government with its authority is obliged to protect medical personnel from the danger of contracting Covid 19, fulfill the need for PPE, and incentives for health workers.

The general public and health professionals must work together and provide support for efforts to reduce Covid-19 cases in Indonesia.

Strengthening the attitude of caring and protecting each other is a slogan that must be instilled in each person.

Consistency in carrying out existing policies is very much needed and supervision carried out by the authorities is the main key in ending the Covid-19 pandemic.

\section{THANK-YOU NOTE}

We would like to thank the Bogor District Health Office for supporting and assisting this writing process.

\section{REFERENCES}

IFSW. (2020). Statement on IFSW and COVID-19". https://www.ifsw.org/statement-onifswandcovid-19/ Directorate General of Disease Prevention and Control, Ministry of Health, Republic of Indonesia. (2020). "Guidelines for the Prevention and Control of Corona Virus 
Disease (COVID-19)", 2020.

Ministry of Health of the Republic of Indonesia. 2020. Guidelines for the Prevention and Control of Coronavirus Disease.

Presidential Decree No. 11/2020 concerning the Determination of the Corona Virus Disease 2019 (COVID-19) Public Health Emergency.

World Health Organization (WHO). 2020. Global surveillance for human infection with the novel coronavirus (2019-ncov). https://www.who.int/publications-detail/global-surveillanceforhuman-infection-with-novel-coronavirus-(2019-ncov). Retrieved March 20, 2020.

Menik Kustriyani Menik Kustriyani, Aji Susanti. K, Arifianto. The Relationship Between Nurse Motivation and Compliance with the Use of Personal Protective Equipment in Inpatient Installations at RSUD dr. Loekmono Hadi Kudus. 2020.

La ode Makta, Dr. dr. H. Noer Bahry Noor, M.ScIrwandy Kapalawi, SKM, M.Sc.PH.MARS. The Influence of Work Motivation with the Performance of Implementing Nurses in the Inpatient Unit of Stella Maris Hospital, Makassar. 2013.

Nova Nurwinda Sari, Dewi Yuliana, Radella Hervidea, Annisa Agata. Covid-19 Health Protocol: As an Effort to Prevent Covid-19 in the Work Area for Office Employees in Bandar Lampung. Journal of Community Care. 2020.

Devi Pramitra Sari, Nabila Sholihah 'Atiqoh. The Relationship Between Public Knowledge And Compliance With The Use Of Masks As An Effort To Prevent Covid-19. INFOKES, 2020.

Ni Putu Emy Darma Yanti, I Made Arie Dharma Putra Nugraha, Gede Adi Wisnawa, Ni Putu Dian Agustina, Ni Putu Arsita Diantari. Overview of Public Knowledge About Covid-19 and Community Behavior During the Covid-19 Pandemic. Journal of Mental Nursing. 2020.

Faura Dea Ayu Pinasti. Analysis of the Impact of the Corona Virus Pandemic on the Level of Public Awareness in the Implementation of Health Protocols. 2020.

Tuti Meihartati. The Importance of Health Protocols in and out of Hospitals During the Covid-19 Pandemic in the Samarinda Community, East Kalimantan. 2020.

Isfauzi Hadi Nugroho. Application of Health Protocols in the New Normal Era in the Early Childhood World.2020.

Nailul Mona. The Concept of Isolation in Social Networks to Minimize Contagious Effects (Corona Virus Spread Cases in Indonesia). Journal of Applied Humanities Social. 2020.

Regulation of the Minister of Health of the Republic of Indonesia Number 9 of (2020). Regarding Guidelines for Large-Scale Social Restrictions in the Context of Accelerating Handling of Corona Virus Disease 2019 (COVID-19).

Karyono. Handling and Prevention of the Corona Virus Outbreak (Covid-19) In Indramayu Regency. Conflict Resolution Collaborative Journal.2020. 
E-ISSN: 2808-5361 http://e-journal.fkmumj.ac.id/
Proceeding The First Muhammadiyah InternasionalPublic Health and Medicine Conference

Syafrida, Ralang Hartat. Together Against the Covid-19 Virus in Indonesia. Social \& Cultural Journal Syar-i.2020.

Tirto. [Internet]. [cited 2021 Mar 3]; Available from: https://tirto.id/apa-itu-3m-to-menharap-menprespenularan-virus-covid-19-f5tV

Fix the Protection of Health Workers. (2020, April 20). Kompas. id. https://kompas.id/baca/bebasaccess/2020/04/20/benahi-perlindungan-terhadap-energi-kesehatan/

Theresia Louize Pesulima, Josiah Hetharie. Legal Protection Against

Occupational Safety for Health Workers Due to the Covid 19 Pandemic. Faculty of Law, Pattimura University, Ambon. Indonesia. 2020.

Legiran. Protect health care workers. Lancet, 395 (10228), 922. 2020.

Salmawati, Lucia. The relationship between the application of occupational safety and health management systems with work motivation and work stress on nurses at Anutapura Palu General Hospital. Journal of health care management. 2015.

Wati, Nopia. Analysis of Occupational Health and Safety Management Systems at Mukomuko Regional General Hospital 2017. Avicenna Journal. 2018. 
Volume I Tahun 2021

November 2021
E-ISSN: 2808-5361

http://e-journal.fkmumj.ac.id/
Proceeding The First Muhammadiyah InternasionalPublic Health and Medicine Conference 